\title{
International Fragmentation of Production and Trade Volatility: An Analysis for the European Countries
}

\author{
Anna Maria Falzoni ${ }^{1}$, Lucia Tajoli ${ }^{2}$ \\ ${ }^{1}$ Department of Management, Economics and Quantitative Methods, Università di Bergamo, Bergamo, Italy \\ ${ }^{2}$ Department of Management, Economics and Industrial Engineering, Politecnico di Milano, Milano, Italy \\ Email: anna-maria.falzoni@unibg.it, lucia.tajoli@polimi.it
}

Received 23 February 2015; accepted 10 March 2015; published 16 March 2015

Copyright (C) 2015 by authors and Scientific Research Publishing Inc.

This work is licensed under the Creative Commons Attribution International License (CC BY). http://creativecommons.org/licenses/by/4.0/

(c) (i) Open Access

\begin{abstract}
In the last years, world exports have displayed very strong fluctuations, much higher than GDP fluctuations. Some recent works tried to understand the causes of these fluctuations, and in particular if these strong swings in world trade flows are related to the growing weight of intermediates in trade and to the phenomenon of international fragmentation of production (IFP) or international outsourcing. This is the issue addressed in this paper. We analyze the influence of international fragmentation of production and trade in intermediate goods on the fluctuations of trade flows for the EU countries. After assessing the relevance of international trade in intermediate goods at the sector level using indices computed from the input-output tables of the EU countries, we test whether a significant relation exists between the extent of international fragmentation of production measured by this proxy and the volatility of trade flows, and the possible implications of these results.
\end{abstract}

\section{Keywords}

Trade Fluctuations, International Outsourcing, Intermediate Goods

\section{Introduction}

A distinctive feature of the recent international economic crisis has been the dramatic effect it displayed on international trade. The trade collapse of 2009, amounting to a fall of $12 \%$ in volume according to the World Trade Organization (WTO) data, was subject of a number of analysis and concerns, as it appeared by far as the 
largest drop since World War II. Quite remarkable and to some extent unexpected was also the fast rebound registered in 2010, when trade increased by 14.5\% [1] suggesting a very strong pro-cyclicality of international trade. Even before the crisis, in the past decade world exports typically displayed fluctuations much stronger than GDP fluctuations, and even if the crisis has amplified this behavior, this might not be a short-term cyclical effect.

Some recent works tried to understand the causes of trade fluctuations [2], and whether the amplified swings in world trade flows are related to structural changes in the composition of trade, in particular to the growing weight of intermediate inputs in trade and to the phenomenon of international fragmentation of production, IFP [3]-[5] or international outsourcing. The relevant role of intermediate inputs for macroeconomic changes in industrialized and industrializing economies has already been highlighted in the literature [6] [7]. Intermediate inputs play an increasingly relevant role also in international trade thanks to the diffusion of international fragmentation of production [8] [9], spreading the different phases of the production chain of a good across many countries, and giving rise to international exchanges of the good at various stages of production across the countries involved [10]. This organization of production can affect world trade volatility through a number of channels.

First of all, it is possible to show that intermediate goods can generate a sort of multiplier in a simple macroeconomic framework, amplifying the variations of many variables, including trade flows. Furthermore, from the accounting point of view, there can be a statistical effect due to the "double counting" of trade values when a good crosses borders many times during different production phases. This can increase the growth of trade over time, but it can also amplify the fall in the low phases of the business cycle [11] [12]. Another possible channel of additional volatility, suggested by some open macroeconomic models, arises because international fragmentation of production can increase the synchronicity of the business cycles of the countries involved in the different phases of the production process by linking demand and production cycles among these countries (see for example [13]-[16]). In presence of IFP, a demand shock for final goods in a country is a demand shock for intermediate goods or components in another, and the resulting effect on inventories of internationally traded components can also affect the supply chain in third countries [17]. Such links can therefore amplify the volatility of the resulting trade flows ${ }^{1}$.

But other models also suggest that the presence of international production chains can have a stabilizing role on international trade. If the costs of setting up a trade relationship to organize an international production network are relevant and sunk for most firms [21] [22], the presence of such costs can make the trade relationships related to IFP quite stable over time, and less volatile than the traditional trade flows of final goods [23].

The relationship between IFP and trade fluctuations suggested by the theory is open to empirical testing. In this paper we want to analyze the influence of international fragmentation of production on the fluctuations of trade flows for the EU countries. As shown in Figure 1, also for the EU27 export flows are strongly pro-cyclical, and the recent international crisis sharply increased trade volatility. EU27 exports slowed down remarkably in 2008, and eventually dropped by more than $16 \%$ in value in 2009, bouncing back almost entirely in 2010. Furthermore, the EU member countries are on average quite open to international trade and are all deeply connected - even if to different extents - to international networks of production and involved in IFP among them and with third countries. Therefore, this group of countries can represent a good sample to look for the existence of a relationship between IFP and trade volatility.

In the following sections, we first present a simplified theoretical framework linking intermediate inputs and macroeconomic fluctuations. We then display some evidence on the extent of volatility of trade flows at the sector level for 20 EU countries, including in the analysis the EU countries for which updated and homogeneous input-output tables of imports are available. These are Austria, Belgium, Denmark, Estonia, Finland, France, Germany, Greece, Hungary, Ireland, Italy, Lithuania, Netherlands, Poland, Portugal, Romania, Slovakia, Slovenia, Spain and Sweden. Unfortunately we cannot include all EU members for lack of homogenous data. We assess the relevance of international fragmentation of production in the manufacturing sectors of those countries, using as a proxy some indices computed from the input-output tables. We then test whether a significant relation exists between international trade in intermediate inputs and the volatility of trade flows in the same sectors, and the possible implications of these results.

\footnotetext{
${ }^{1}$ Very recent studies have focused on the role of firms in the business cycles, arguing that idiosyncratic shocks to individual firms significantly contribute to aggregate fluctuations (see for example [18]-[20]).
} 


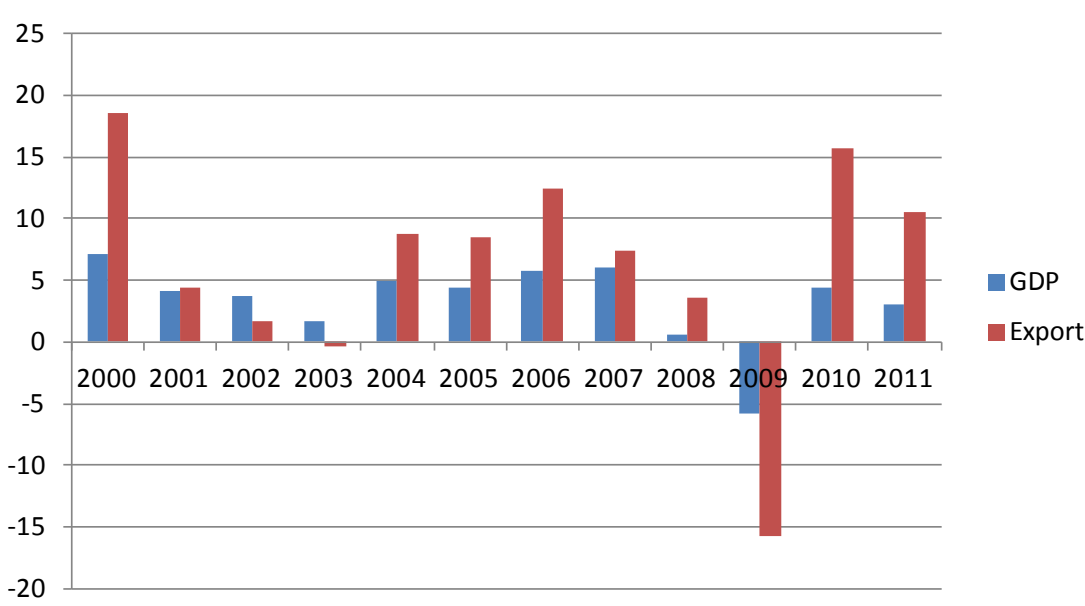

Figure 1. Yearly percent variations in EU27 GDP and export 2000-2011 at current prices. Source: Eurostat.

\section{Macroeconomic Fluctuations and Intermediate Goods}

The idea that linkages between sectors created by intermediate goods are central to economic performance has been around for nearly a century, but it was kept in the background for a long time. As the need of physical proximity to perform different tasks and different stages of production in many sectors diminished, the practice to outsource segments of production to other industrial sectors has increased and the role of intermediate inputs gained new relevance. With the reduction of barriers to international trade, outsourcing became increasingly international, generating flows of trade in intermediate goods.

It is fairly straight forward to show that linkages between sectors can generate a multiplier similar to other multipliers associated with macroeconomic variables. A recent paper by [7] presents a simple example showing how such a multiplier can work. Assume gross output $Q_{t}$ is produced using primary factors of production (e.g. $K_{t}$ and $L_{t}$ ) and intermediate goods $X_{t}$ according to the expression:

$$
Q_{t}=A\left(K_{t}^{\alpha} L_{t}^{1-\alpha}\right)^{1-\sigma} X_{t}^{\sigma}
$$

where $0<\alpha, \sigma<1$. Gross output can be used for consumption or investment, but also as an intermediate good. In this very simplified framework, it is assumed that a constant share $\bar{x}$ of gross output is used as an intermediate good, so that gross domestic product in this economy is defined as $Y_{t}=(1-\bar{x}) Q_{t}$ and

$$
X_{t+1}=\bar{x} Q_{t}
$$

Assuming that also investments are a constant share of GDP, and that they depreciate at a constant rate, in steady state GDP is given by

$$
Y=\left[\bar{A}(1-\bar{x})^{1-\sigma} \bar{x}^{\sigma}\right]^{1 /(1-\sigma)}\left(K_{t}^{\alpha} L_{t}^{1-\alpha}\right)
$$

In this framework, changes in the allocation of resources defined by $\bar{x}$ are amplified by the multiplier given by $1 /(1-\sigma)$. It is also worth noting that the effect of changes in $\bar{x}$ on $Y$ depends crucially on the level of $\sigma$, which represents the importance of intermediate goods in the aggregate production function.

If the economy opens up and international fragmentation of production becomes possible, and intermediate inputs can be imported, expression (1) will be modified so that intermediate goods used in production become $\left(X_{t}+O_{t}\right)$, where $O_{t}$ represents imported intermediate inputs. Import of intermediate goods can change $\bar{x}$, and it might also increase the total amount of intermediate inputs used, also changing the GDP level. Importing intermediate goods makes possible to reach a higher GDP with the same factors' endowment in the short run, as gross output is positively related to the total amount of inputs used in production ${ }^{2}$. The impact of imported inputs on gross output needs not to be the same as the domestic inputs (if for example imported inputs have a

${ }^{2}$ Reference [24] shows that GDP growth in the EU is indeed positively correlated with the extent of international fragmentation of production. 
different technological content). But the relationship between $\bar{x}$ and $Y$ in (3) is non-monotonic (hump-shaped) and reductions in $\bar{x}$ will increase $Y$ in steady state only up to a point ${ }^{3}$. Changes in the amount of imported inputs can therefore per se give rise to variations in GDP. If we further assume that also imported intermediate inputs are proportional to gross output and inversely proportional to $\bar{x}$, we have in this framework a co-cyclical behavior of trade and output driven by the supply-side of the economy, additional to the aggregate demand pro-cyclicity ${ }^{4}$. Therefore, in presence of trade in intermediate goods, changes in the economy can give rise to variations in trade flows much stronger than the ones expected considering only demand for final goods.

Even in this very simplified framework, the correlation of the movements of GDP and trade depends on a number of parameters, first of all on $\bar{x}, \sigma$, and the ratio of imported inputs over total inputs used. This means that a correlation between IFP and high volatility in trade flows can occur for some countries and some industries, but it is very difficult to generalize such a relationship.

\section{Trade Volatility in the EU Countries}

The expressions in the previous section representing the aggregate economy can be seen as the (geometric) average of sectoral production functions, using intermediate goods to different extents. Previous results in the literature stress the different cyclical properties of trade flows of different types of goods, and especially of durable and non-durables [25] [26]. For these reasons, it is important to examine the behavior of trade flows at the sector level. Here we consider 22 manufacturing sectors ${ }^{5}$, and indeed the extent of fluctuations of EU trade flows appears quite differentiated across sectors.

In what follows, the volatility of trade flows is measured first of all in terms of standard deviations of quarterly trade values at current prices over the observation period, 1999-2011 and in the years of the crisis, 20082011. These standard deviations of trade flows are normalized by taking their ratio on GDP standard deviations over the same period ${ }^{6}$. We also compute volatility as the standard deviation of quarterly percentage changes in the value of export and import in each sector. Table 1(a) and Table 1(b) report the average variation of imports and exports of the $20 \mathrm{EU}$ countries considered for all manufacturing sectors.

As expected, volatility is generally high in many advanced or durable goods sectors, like motor vehicles and transport equipment, office machinery and communication equipment. Depending on the measure used, volatility is also high in some traditional sectors producing consumers' goods, such as apparel. We can also observe that variations in export and imports flows appear correlated, as shown in other works.

The volatility of trade flows increased sharply during the international economic crisis in many sectors. On average, but also for a number of sectors and countries, trade volatility in the 2008-2011 period is higher than the average volatility in the 1999-2011 period, even if also in this respect we can observe differences across sectors. In some sectors we have a collapse of trade at the beginning of 2009, with a drop of trade values on a year-to-year basis over $30 \%$, with a strong rebound in the following quarters, while in other sectors trade remains much more stable, and a few cases even display a modest growth.

\section{International Fragmentation of Production and Trade in Intermediate Goods in the EU Countries}

Many sectors' characteristics can influence the observed differences in volatility, both because of the organization of production and because of demand patterns. As mentioned, we focus on the role of IFP and on trade in intermediate goods related to IFP, putting aside the possible role of other factors.

There is not a uniquely identified indicator to measure the extent of IFP in any given sector. The very definition of IFP often slightly changes moving from one work and context to another, let alone any precise measurement of this phenomenon. Here we use the data available in the input-output (I-O) tables provided by Eurostat for the year 2000 and 2005 to build two different indices of intermediate goods trade. The first is the so-called index of narrow offshoring, commonly used in the literature to measure the share of imported intermediate

\footnotetext{
${ }^{3}$ Note that even with an increase in GDP this does not necessary imply a higher level of consumption in the same period or in the steady state, as imports will have to be paid with exports, absorbing a part of GDP. Therefore, welfare implications are not straight forward.

${ }^{4}$ Considering the demand side of the economy and imports of final goods are proportional to GDP, also displaying the usual pro-cyclical behavior.

${ }^{5}$ We adopt the sectoral disaggregation used in Eurostat input-output tables, compiled following the classification NACE Rev. 1.

${ }^{6}$ Our volatility measure is equivalent to the one used by [25].
} 
Table 1. (a) Average volatility indices of trade flows relative to GDP in EU manufacturing sectors; (b) Average volatility indices of trade flows in EU manufacturing sectors.

(a)

\begin{tabular}{|c|c|c|c|c|c|}
\hline Manufacturing sectors & $\begin{array}{c}\text { Sector code } \\
\text { (NACE Rev. 1) }\end{array}$ & $\begin{array}{l}\text { Export st. dev. } \\
\text { in \% of GDP st. } \\
\text { dev. 1999-2011 }\end{array}$ & $\begin{array}{l}\text { Export st. dev. } \\
\text { in \% of GDP st. } \\
\text { dev. 2008-2011 }\end{array}$ & $\begin{array}{l}\text { Import st.dev. } \\
\text { in \% of GDP st. } \\
\text { dev. 1999-2011 }\end{array}$ & $\begin{array}{l}\text { Import st. dev. } \\
\text { in \% of GDP st. } \\
\text { dev. 2008-2011 }\end{array}$ \\
\hline Food and beverages & 15 & 3.87 & 6.17 & 3.95 & 4.94 \\
\hline Tobacco products & 16 & 0.24 & 0.46 & 0.19 & 0.42 \\
\hline Textiles & 17 & 0.68 & 1.44 & 0.63 & 1.62 \\
\hline Wearing apparel & 18 & 1.02 & 2.29 & 1.24 & 2.85 \\
\hline Leather and footwear & 19 & 0.55 & 1.57 & 0.66 & 1.71 \\
\hline Products of wood and cork (exc. furniture) & 20 & 0.92 & 1.78 & 0.65 & 1.13 \\
\hline Paper and paper products & 21 & 1.11 & 2.42 & 0.68 & 1.39 \\
\hline Publishing and printing & 22 & 0.29 & 0.49 & 0.19 & 0.44 \\
\hline Manufacture of fuels & 23 & 5.74 & 13.02 & 5.09 & 10.71 \\
\hline Chemicals and chemical products & 24 & 9.86 & 13.59 & 8.03 & 10.41 \\
\hline Rubber and plastic products & 25 & 1.91 & 3.43 & 1.66 & 2.70 \\
\hline Other non-metallic mineral products & 26 & 0.71 & 1.48 & 0.70 & 1.39 \\
\hline Manufacture of basic metals & 27 & 5.35 & 11.84 & 5.75 & 12.78 \\
\hline $\begin{array}{l}\text { Fabricated metal products } \\
\text { (exc. machinery and equipment) }\end{array}$ & 28 & 1.91 & 3.17 & 1.67 & 3.05 \\
\hline Machinery and equipment n.e.c. & 29 & 5.76 & 10.30 & 4.43 & 9.67 \\
\hline Office machinery and computers & 30 & 2.29 & 3.86 & 2.10 & 4.66 \\
\hline Electrical machinery and apparatus n.e.c. & 31 & 3.07 & 5.31 & 2.34 & 4.40 \\
\hline Communication equipment and apparatus & 32 & 6.02 & 11.37 & 4.97 & 10.14 \\
\hline Precision and optical instruments & 33 & 1.93 & 3.07 & 1.53 & 2.38 \\
\hline Motor vehicles, trailers and semi-trailers & 34 & 6.86 & 14.45 & 6.36 & 15.16 \\
\hline Other transport equipment & 35 & 1.72 & 4.16 & 2.04 & 5.41 \\
\hline Furniture; manufacturing n.e.c. & 36 & 1.50 & 2.84 & 1.38 & 2.54 \\
\hline
\end{tabular}

Source: our elaborations from Eurostat database.

(b)

\begin{tabular}{|c|c|c|c|c|c|}
\hline Manufacturing sectors & $\begin{array}{c}\text { Sector code } \\
\text { (NACE Rev. 1) }\end{array}$ & $\begin{array}{c}\text { St. dev. of \% } \\
\text { quart. change } \\
\text { of export } \\
\text { 1999-2011 }\end{array}$ & $\begin{array}{l}\text { St. dev. of \% } \\
\text { quart. change } \\
\text { of export } \\
2008-2011\end{array}$ & $\begin{array}{c}\text { St. dev. of \% } \\
\text { quart. change } \\
\text { of import } \\
\text { 1999-2011 }\end{array}$ & $\begin{array}{c}\text { St. dev. of \% } \\
\text { quart. change } \\
\text { of import } \\
2008-2011\end{array}$ \\
\hline Food and beverages & 15 & 10.52 & 8.52 & 9.46 & 8.02 \\
\hline Tobacco products & 16 & 54.69 & 69.87 & 80.23 & 43.35 \\
\hline Textiles & 17 & 9.87 & 9.98 & 11.92 & 12.81 \\
\hline Wearing apparel & 18 & 24.22 & 24.81 & 26.26 & 26.88 \\
\hline Leather and footwear & 19 & 21.02 & 24.11 & 25.50 & 29.51 \\
\hline Products of wood and cork (exc. furniture) & 20 & 11.46 & 11.81 & 11.40 & 12.10 \\
\hline
\end{tabular}




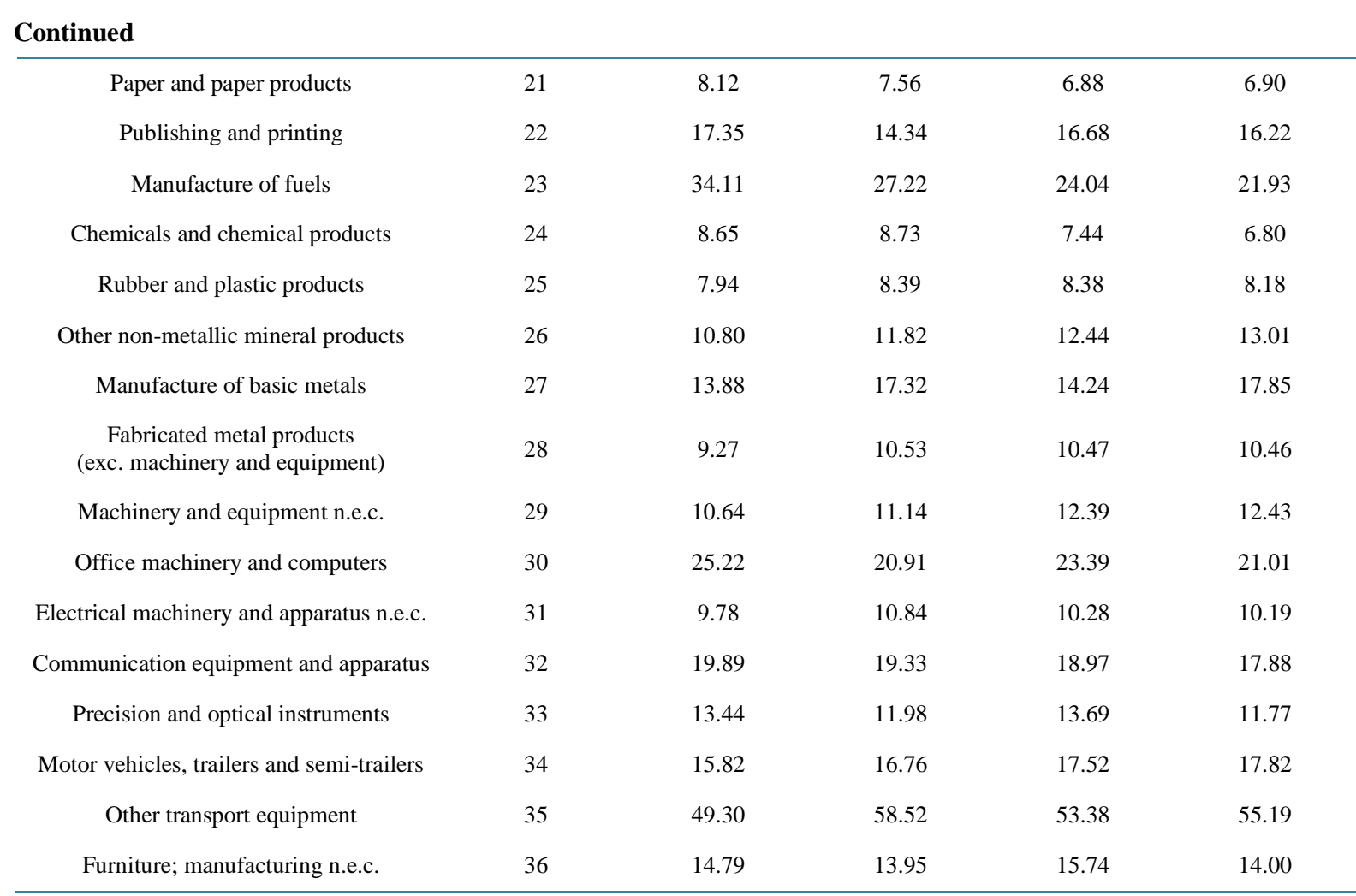

Source: our elaborations from Eurostat database.

inputs belonging to sector $i$ and employed for production in the same sector ${ }^{7}$. This index should provide an approximate measure of the amount of production of a given good that takes place abroad and is then embodied in the final good through the use of imported inputs, and therefore it is used as a proxy of IFP. The index for country $c$ and manufacturing sector $i$ has the following expression:

$$
\text { Off }_{i c}=a_{i i} / \sum_{i}\left(\text { intermediate inputs }_{i}\right)_{i}
$$

where $a_{i i}$ is the cell of the I-O matrix for imports measuring the value of imported intermediate inputs $i$ employed in the same sector $i$, and at the denominator we have the total value of all intermediate inputs used in production in sector $i$.

The second index that we use measures instead the weight of imports of intermediate goods $j$ on the total value of imports of a given sector. This index is obtained as the ratio between the sum by row of the import I-O table and the total value of all imports in the same sector:

$$
\text { InterImp }_{i c}=\sum_{j}\left(\text { import interm. inputs }_{j}\right)_{i} / \text { tot Imp }_{i}
$$

This index should instead capture the share of import flows in each sector that is directly affected by the production cycle rather than by final demand.

In Figure 2 and Figure 3 we report the indices for the year 2005, a year for which import I-O tables are available for the majority of EU countries from Eurostat, before the effects of the international crisis are felt. The indices aim at measuring some structural characteristics of the economies and manufacturing sectors of our sample, and although they may change over long time periods, they remain relatively stable over a few years. Both indices should capture the relevance of intermediate goods trade at the sector and country level, but the correlation between the two indices across sectors and countries is quite low, equal to 0.15 for the entire sample. The two indices in fact present different features of trade in intermediate goods. The narrow offshoring index can reveal some characteristics of the organization of production, as it measures the weight of imported inputs

\footnotetext{
${ }^{7}$ This index was originally introduced by [27], and subsequently improved thanks to the use of input-output tables for imports. For a discussion on the use of this index, see for example [28].
} 


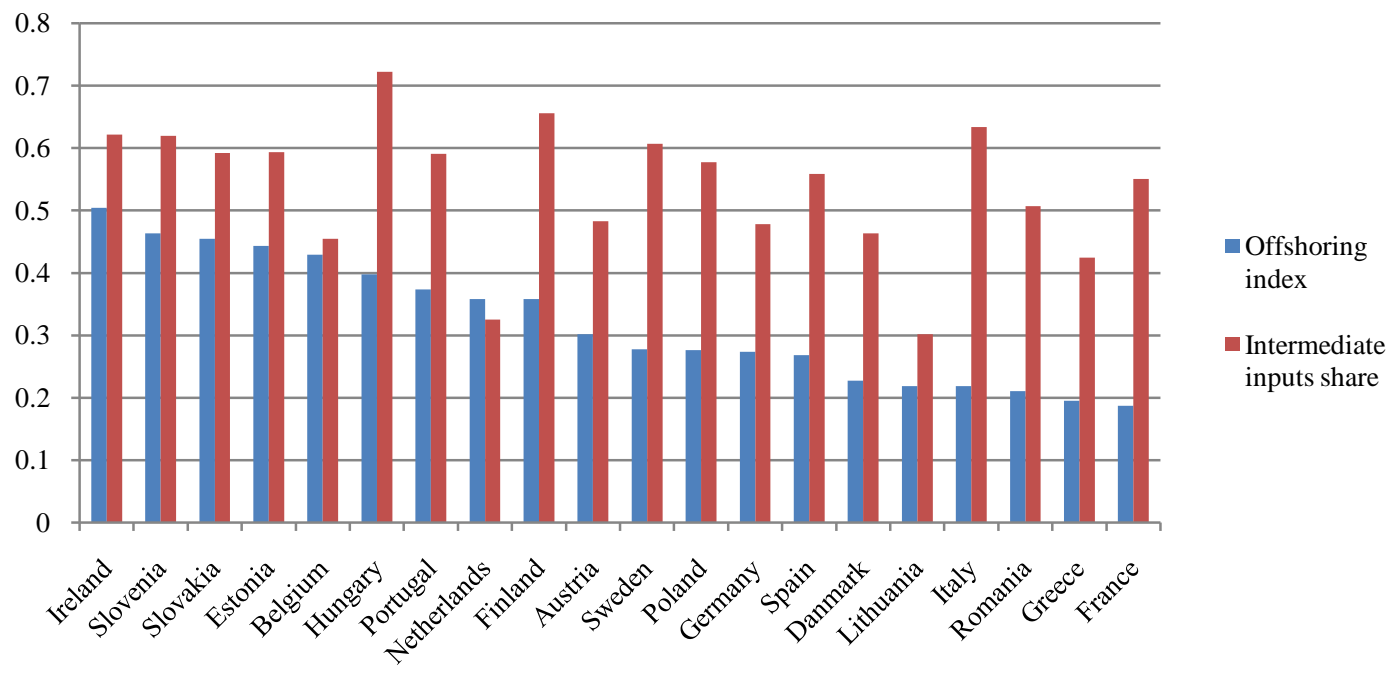

Figure 2. Average offshoring indices and intermediates' share over total imports in EU countries in 2005 (Indices are weighted averages of each country's indices in each industry).
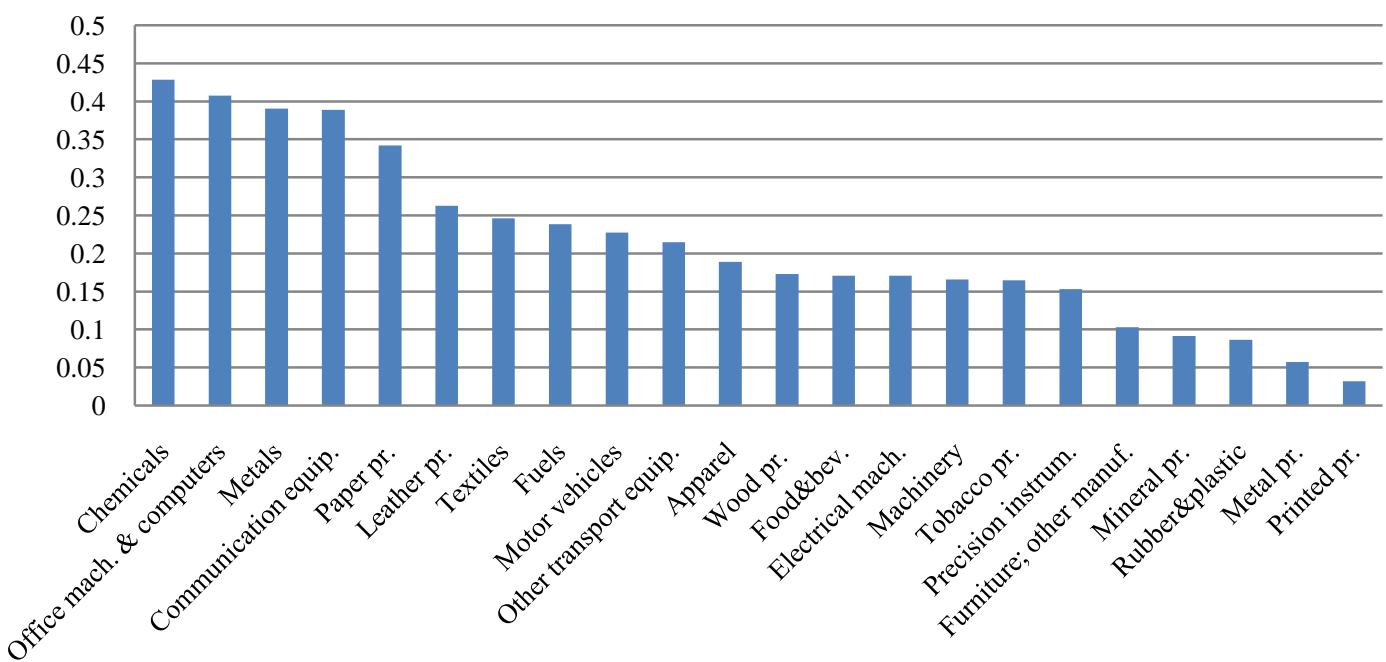

Figure 3. Average offshoring indices in the EU across industries in 2005 (Indices are weighted averages of 20 EU countries' indices in each industry).

from the point of view of producing sectors. Instead the intermediate import ratio index should capture the relative weight of two components of the import demand, one coming from firms, demanding intermediate inputs for production, and the rest coming from final consumers demanding final goods. Even if the narrow offshoring index appears more appropriate to capture the extent of IFP, which is determined by producers and firms' choices, in terms of explaining the volatility of trade flows also the other index more focused on demand could provide some indications.

Figure 2 presents the weighted average indices of narrow offshoring and trade in intermediate goods for the EU countries. Many of the new EU members, highly involved in international production chains, show relatively high narrow offshoring indices. The intermediate imports ratio is quite high for all countries, confirming that imports of intermediate inputs count for at least one third of imports for most EU countries.

Looking at Figure 3, reporting the weighted average indices for each sector, we observe that sectoral characteristics are quite different also with respect to the relevance of trade in intermediates. In the adopted classification, some sectors produce a very limited amount of final goods, and therefore present a very high ratio of imported intermediate inputs (e.g. basic metals, NACE code 27). But also the narrow offshoring index displays 
large differences across sectors. Generally, the indices for the EU countries are in line with the existing evidence suggesting that some sectors (e.g. office machinery, NACE code 30 or communication equipment, NACE code 32) are highly involved in IFP.

\section{The Relationship between Trade Volatility and Trade in Intermediate Goods}

Is the high share of intermediate goods in international trade-confirmed also for the EU countries-associated with high volatility and instability of trade flows? Some recent empirical evidence produced in particular for the US in the context of the recent international economic crisis seems to confirm this hypothesis, even if the results are not always robust [4] [26].

For our sample of EU countries, the overall simple correlation for the period 1999-2011 between the measures of intermediate goods trade and volatility of trade flows is positive, but not very high, with a value slightly higher than 0.30 both for imports and exports. We also observe a positive and significant correlation between the share of sector's imports over GDP and the volatility both of imports and exports: more openness is associated with higher volatility of trade flows, which is plausible, and it is in line with the existing evidence for other countries [16].

We then must test the significance of the relationship between trade in intermediate goods and trade volatility adding the appropriate control variables, to condition results on the characteristics of the industries involved, as suggested by the theoretical framework sketched in Section $2^{8}$. Results are reported in Table 2 and Table 3.

Considering our main variables of interest over the period 1999-2011, we observe that the narrow offshoring index is not always significantly correlated with the measures of trade volatility. Controlling for countries and industries characteristics using fixed effects, the narrow offshoring coefficient is positive and significant when regressed against import volatility, and it remains so adding further controls, but it becomes non-significant when a general openness measure is introduced. The relationship appears even less robust with respect to export volatility.

We introduced in the regressions a dummy variable separating old and new EU members (taking value 1 if the country belongs to the EU15 group of old members), as the position that the two groups of countries hold in the international production chain is markedly different. The narrow offshoring index can in fact be correlated to trade volatility in a different way according to the organization and decision process along the production chain. The EU dummy always displays a negative sign, indicating that the old EU member countries' trade has generally a lower volatility, and in some regressions, the effect of the variable is to increase the significance of the narrow offshoring coefficient. Offshoring affects especially trade fluctuations in the new EU member countries where production phases have been delocalized from old EU members ${ }^{9}$.

Considering the ratio between imported intermediate inputs and total imports (Table 3), this is never significantly correlated with the volatility of imports, but it displays a positive and significant coefficient in relation with export volatility. Also in this case, this positive correlation could depend from the high content of imported inputs that exports require, while a higher share of intermediate inputs over total imports per se does not affect the volatility of this flow.

Overall, these results give very weak support to the view that more international fragmentation of production has systematically increased trade volatility. They confirm the evidence of some correlation between the two, but this relationship is very contingent on the specific situation analyzed.

The relationship between trade volatility and trade in intermediate goods is more robust if we consider only the years of the largest trade swings, covering the most turbulent period of the economic and financial crisis. In Table 4 we report the estimates of this relation for volatility over 2008-2010, and we observe a higher goodness-of-fit of the regression for this time frame, as well as a higher and more significant coefficients for the narrow offshoring indices than for the entire decade. Also the coefficient of the share of intermediate inputs over production is reinforced.

Much less stable is the sign and the significance of the share of inputs on total imports. The effect on import volatility is negative, showing that during the shock production relationships seemed more persistent than final

\footnotetext{
${ }^{8}$ We should stress that the reported regressions, even if introducing some control variables, are only testing the correlation between the two variables of interest and no causality or structural relationship can be inferred from these results at this stage. In fact, volatility of trade flows is likely to be influenced by a number of additional factors, that we omit in these regressions.

${ }^{9}$ This result is in line with the evidence produced by [29] and the related theoretical model ([30]), showing that the volatility of the sectors most involved in IFP between the U.S. and Mexico, in Mexico appeared much higher than in the U.S.
} 
Table 2. Volatility of trade flows and offshoring over the period 1999-2011.

\begin{tabular}{|c|c|c|c|c|c|c|c|c|c|c|}
\hline \multirow{3}{*}{$\begin{array}{c}\text { Explanatory } \\
\text { variables } \\
\begin{array}{c}\text { Narrow } \\
\text { offshoring }^{(b)}\end{array}\end{array}$} & \multicolumn{10}{|c|}{ Dependent variable ${ }^{(a)}$} \\
\hline & \multirow[b]{2}{*}{$\begin{array}{c}0.0150 \\
(0.0084)^{*}\end{array}$} & \multicolumn{4}{|c|}{$\begin{array}{c}\text { Import volatility } \\
\text { (normalized st. dev. of import 1999-2011) }\end{array}$} & \multicolumn{5}{|c|}{$\begin{array}{c}\text { Export volatility } \\
\text { (normalized st. dev. of export 1999-2011) }\end{array}$} \\
\hline & & $\begin{array}{c}0.0148 \\
(0.0083)^{*}\end{array}$ & $\begin{array}{l}-0.0107 \\
(0.0066)\end{array}$ & $\begin{array}{l}0.0354 \\
(0.0077)^{* * *}\end{array}$ & $\begin{array}{l}-0.0083 \\
(0.0058)\end{array}$ & $\begin{array}{c}0.0123 \\
(0.0132)\end{array}$ & $\begin{array}{c}0.0164 \\
(0.0127)\end{array}$ & $\begin{array}{l}-0.0184 \\
(0.0109)^{*}\end{array}$ & $(0.0116)^{* * *}$ & $\begin{array}{l}-0.0136 \\
(0.0096)\end{array}$ \\
\hline $\begin{array}{l}\text { Inputs over } \\
\text { production }\end{array}$ & & $\begin{array}{c}0.0121 \\
(0.0166)\end{array}$ & $\begin{array}{l}-0.0215 \\
(0.0129)^{*}\end{array}$ & $\begin{array}{c}0.0285 \\
(0.0151)^{*}\end{array}$ & $\begin{array}{l}-0.0174 \\
(0.0109)\end{array}$ & & $\begin{array}{c}0.0433 \\
(0.0254)^{*}\end{array}$ & $\begin{array}{c}0.0014 \\
(0.0214)\end{array}$ & $\begin{array}{l}0.0586 \\
(0.0228)^{* *}\end{array}$ & $\begin{array}{l}-0.0003 \\
(0.0179)\end{array}$ \\
\hline Import value $^{(\mathrm{b})}$ & & $\begin{array}{l}6.07 \mathrm{e}-07 \\
\left(2.14 \mathrm{e}^{-07}\right)^{* * *}\end{array}$ & & $\begin{array}{l}3.49 \mathrm{e}-07 \\
\left(1.55 \mathrm{e}^{-07}\right)^{* *}\end{array}$ & & & $\begin{array}{l}1.18 \mathrm{e}^{-06} \\
\left(3.27 \mathrm{e}^{-07)}\right)^{* * *}\end{array}$ & & $\begin{array}{l}7.69 \mathrm{e}-07 \\
(2.34 \mathrm{e}-07)^{* * * *}\end{array}$ & \\
\hline Import/GDP ${ }^{(b)}$ & & & $\begin{array}{l}1.5494 \\
(0.0927)^{* * *}\end{array}$ & & $\begin{array}{l}1.3729 \\
(0.0834)^{* * *}\end{array}$ & & & $\begin{array}{l}2.1045 \\
(0.1539)^{* * *}\end{array}$ & & $\begin{array}{l}1.7771 \\
(0.1367)^{* * *}\end{array}$ \\
\hline Dummy EU15 & & & & $\begin{array}{l}-0.0069 \\
(0.0027)^{* * *}\end{array}$ & $\begin{array}{l}-0.0048 \\
(0.0025)^{*}\end{array}$ & & & & $\begin{array}{l}-0.0072 \\
(0.0040)^{*}\end{array}$ & $\begin{array}{l}-0.0069 \\
(0.0042)^{*}\end{array}$ \\
\hline Import/GDP*EU15 & & & & & $\begin{array}{l}0.9122 \\
(0.1091)^{* * *}\end{array}$ & & & & & $\begin{array}{l}1.4938 \\
(0.1789)^{* * *}\end{array}$ \\
\hline Country dummy & yes & yes & yes & no & no & yes & yes & yes & no & no \\
\hline Sector dummy & yes & yes & yes & yes & yes & yes & yes & yes & yes & yes \\
\hline No. observations & 434 & 432 & 432 & 432 & 432 & 434 & 432 & 432 & 432 & 432 \\
\hline $\mathrm{R}^{2}$ & 0.5594 & 0.5702 & 0.7448 & 0.5001 & 0.7472 & 0.4191 & 0.4487 & 0.6154 & 0.3801 & 0.6285 \\
\hline
\end{tabular}

Note: Standard errors in parenthesis. Coefficients with ${ }^{* * *},{ }^{* *},{ }^{*}$ are significant at $99 \%, 95 \%$ e $90 \%$ respectively. ${ }^{\text {(a) }}$ Volatility is computed in terms of standard deviation of quarterly imports and exports in the period 1999Q1-2011Q4 (or 2008Q1-2011Q4). The volatility index of imports and exports is taken as the ratio of these flows standard deviations and the standard deviations of GDP in the corresponding period. ${ }^{\text {(b) }}$ Variables computed for the year 2005, All data used to build the variables come from Eurostat.

Table 3. Volatility of trade flows and intermediates trade over the period 1999-2011.

\begin{tabular}{|c|c|c|c|c|c|c|c|c|}
\hline \multirow{3}{*}{$\begin{array}{c}\begin{array}{c}\text { Explanatory } \\
\text { variables }\end{array} \\
\text { Imported inputs } \\
\text { over total import }^{(\mathrm{b})}\end{array}$} & \multicolumn{8}{|c|}{ Dependent variable $\mathrm{e}^{(\mathrm{a})}$} \\
\hline & \multicolumn{4}{|c|}{$\begin{array}{c}\text { Import volatility } \\
\text { (normalized st. dev. of import 1999-2011) }\end{array}$} & \multicolumn{4}{|c|}{$\begin{array}{l}\text { Export volatility } \\
\text { (normalized st. dev. of export 1999-2011) }\end{array}$} \\
\hline & $\begin{array}{c}0.0066 \\
(0.0087)\end{array}$ & $\begin{array}{c}0.0021 \\
(0.0090)\end{array}$ & $\begin{array}{l}-0.0109 \\
(0.0082)\end{array}$ & $\begin{array}{l}-0.0080 \\
(0.0057)\end{array}$ & $\begin{array}{c}0.0466 \\
(0.0133)^{* * *}\end{array}$ & $\begin{array}{c}0.0377 \\
(0.0136)^{* * *}\end{array}$ & $\begin{array}{c}0.0186 \\
(0.0122)\end{array}$ & $\begin{array}{l}0.0228 \\
(0.0093)^{* *}\end{array}$ \\
\hline $\begin{array}{l}\text { Inputs over } \\
\text { production }\end{array}$ & & $\begin{array}{c}0.0111 \\
(0.0170)\end{array}$ & $\begin{array}{c}0.0445 \\
(0.0160)^{* * *}\end{array}$ & $\begin{array}{l}-0.0136 \\
(0.0114)\end{array}$ & & $\begin{array}{c}0.0285 \\
(0.0258)\end{array}$ & $\begin{array}{c}0.0622 \\
(0.0239)^{* *}\end{array}$ & $\begin{array}{l}-0.0136 \\
(0.0185)\end{array}$ \\
\hline Import value ${ }^{(b)}$ & & $\begin{array}{c}5.97 \mathrm{e}-07 \\
(2.16 \mathrm{e}-07)^{* * *}\end{array}$ & $\begin{array}{c}2.70 \mathrm{e}-07 \\
(1.58 \mathrm{e}-07)^{*}\end{array}$ & & & $\begin{array}{l}1.08 \mathrm{e}-06 \\
\left(3.26 \mathrm{e}^{-0}-07\right)^{* * *}\end{array}$ & $\begin{array}{c}6.81 \mathrm{e}-07 \\
(2.37 \mathrm{e}-07)^{* * *}\end{array}$ & \\
\hline Import/GDP ${ }^{(\mathrm{b})}$ & & & & $\begin{array}{c}1.3339 \\
(0.0788)^{* * *}\end{array}$ & & & & $\begin{array}{c}1.7147 \\
(0.1286)^{* * *}\end{array}$ \\
\hline Dummy EU15 & & & $\begin{array}{c}-0.0078 \\
(0.0027)^{* * *}\end{array}$ & $\begin{array}{l}-0.0048 \\
(0.0025)^{*}\end{array}$ & & & $\begin{array}{c}-0.0079 \\
(0.0041)^{*}\end{array}$ & $\begin{array}{l}-0.0066 \\
(0.0041)\end{array}$ \\
\hline Import/GDP*EU15 & & & & $\begin{array}{c}0.8914 \\
(0.1088)^{* * *}\end{array}$ & & & & $\begin{array}{c}1.4884 \\
(0.1774)^{* * *}\end{array}$ \\
\hline Country dummy & yes & yes & no & no & yes & yes & no & no \\
\hline Sector dummy & yes & yes & yes & yes & yes & yes & yes & yes \\
\hline No. observations & 435 & 432 & 432 & 432 & 435 & 432 & 432 & 432 \\
\hline $\mathrm{R}^{2}$ & 0.5576 & 0.5667 & 0.4763 & 0.7472 & 0.4396 & 0.4571 & 0.3583 & 0.6322 \\
\hline
\end{tabular}

Note: See Notes to Table 2. 


\begin{tabular}{|c|c|c|c|c|c|c|c|c|c|}
\hline \multirow{3}{*}{$\begin{array}{c}\begin{array}{c}\text { Explanatory } \\
\text { variables }\end{array} \\
\begin{array}{c}\text { Narrow } \\
\text { offshoring }^{(b)}\end{array}\end{array}$} & \multicolumn{9}{|c|}{ Dependent variable ${ }^{(a)}$} \\
\hline & \multicolumn{4}{|c|}{$\begin{array}{l}\text { Import volatility } \\
2008-2010\end{array}$} & \multicolumn{5}{|c|}{$\begin{array}{l}\text { Export volatility } \\
2008-2010\end{array}$} \\
\hline & $\begin{array}{c}0.0444 \\
(0.0128)^{* * *}\end{array}$ & $\begin{array}{c}0.0443 \\
(0.0127)^{* * *}\end{array}$ & $\begin{array}{l}0.0805 \\
(0.0125)^{* * *}\end{array}$ & & $\begin{array}{c}0.0175 \\
(0.0194)\end{array}$ & $\begin{array}{c}0.0238 \\
(0.0184)\end{array}$ & $\begin{array}{l}0.0771 \\
(0.0174)^{* * *}\end{array}$ & & \\
\hline $\begin{array}{l}\text { Imported inputs } \\
\text { over total imports }^{(\mathrm{b})}\end{array}$ & & & & $\begin{array}{l}-0.0241 \\
(0.0136)^{*}\end{array}$ & & & & $\begin{array}{c}0.0673 \\
(0.0196)^{* * *}\end{array}$ & $\begin{array}{c}0.0274 \\
(0.0184)\end{array}$ \\
\hline $\begin{array}{l}\text { Inputs over } \\
\text { production }\end{array}$ & & $\begin{array}{l}0.0554 \\
(0.0253)^{* *}\end{array}$ & $\begin{array}{l}0.1016 \\
(0.0248)^{* * *}\end{array}$ & $\begin{array}{l}0.1375 \\
(0.0266)^{* * *}\end{array}$ & & $\begin{array}{l}0.1078 \\
(0.0367)^{* * *}\end{array}$ & $\begin{array}{l}0.1488 \\
(0.0343)^{* * *}\end{array}$ & $\begin{array}{l}0.0814 \\
(0.0370)^{* *}\end{array}$ & $\begin{array}{c}0.1563 \\
(0.0361)^{* * *}\end{array}$ \\
\hline Import value ${ }^{(\mathrm{b})}$ & & $\begin{array}{l}8.39 \mathrm{e}-07 \\
(3.25 \mathrm{e} 07)^{* *}\end{array}$ & $\begin{array}{l}4.62 \mathrm{e}-07 \\
(2.53 \mathrm{e}-07)^{*}\end{array}$ & $\begin{array}{c}2.81 \mathrm{e}-07 \\
\left(2.64 \mathrm{e}^{-07)}\right.\end{array}$ & & $\begin{array}{l}2.16 \mathrm{e}-06 \\
(4.73 \mathrm{e} 07)^{* * *}\end{array}$ & $\begin{array}{l}1.34 \mathrm{e}-06 \\
\left(3.52 \mathrm{e}-07^{* * *}\right.\end{array}$ & $\begin{array}{c}1.99 \mathrm{e}-06 \\
(4.69 \mathrm{e}-07)^{* * *}\end{array}$ & $\begin{array}{l}1.20 \mathrm{e}-06 \\
(3.57 \mathrm{e}-07)^{* * *}\end{array}$ \\
\hline Dummy EU-15 & & & $\begin{array}{l}-0.0035 \\
(0.0043)\end{array}$ & $\begin{array}{l}-0.0055 \\
(0.0045)\end{array}$ & & & $\begin{array}{l}-0.0019 \\
(0.0060)\end{array}$ & & $\begin{array}{l}-0.0032 \\
(0.0062)\end{array}$ \\
\hline Country dummy & yes & yes & no & no & yes & yes & no & yes & no \\
\hline Sector dummy & yes & yes & yes & yes & yes & yes & yes & yes & yes \\
\hline No. observations & 434 & 432 & 432 & 432 & 433 & 431 & 431 & 431 & 431 \\
\hline $\mathrm{R}^{2}$ & 0.6997 & 0.7101 & 0.6130 & 0.5771 & 0.4929 & 0.5393 & 0.4386 & 0.5511 & 0.4146 \\
\hline
\end{tabular}

Note: See Notes to Table 2.

demand, as it could be expected. The share of imported inputs is instead positively correlated with export volatility. In this period, the EU15 dummy variable is never significant, even if maintaining the negative sign, hinting to the fact that some convergence in the production structures might have occurred over time between old and new members of the EU, or that the shock due to the crisis might have blurred some of the differences between groups of EU members.

\section{Concluding Remarks}

In conclusion, the evidence of a relationship between volatility of trade flows and the extent of trade in intermediate goods for the EU countries does not appear very robust. The relationship seems to depend on countries and sectors' characteristics, but this result cannot be generalized for the entire Europe in the past decade. The link between trade volatility and trade in intermediates was stronger when the international financial crisis hit Europe: during the crisis, trade flows fluctuations have been stronger (both in terms of falls and rises) in those sectors and countries displaying a higher offshoring index. These results are broadly in line with the theory suggesting that this relationship is contingent on a number of factors.

These results are still quite preliminary, as a longer observation period after the crisis is necessary to check whether the observed correlation between trade in intermediates and trade volatility during the crisis is a spurious one. In fact, the very strong shock brought with the crisis can be the common cause of many observed fluctuations of economic variables in EU countries, without a direct relationship between the variables themselves. But if confirmed, these results have interesting positive and normative implications: the increase of international production linkages through trade in intermediate inputs does not necessarily imply a higher volatility of trade flows and a higher exposure to shocks. Therefore, the increased economic integration of the national economies through production linkages might speed up the transmission of shocks, but it needs not to increase the overall instability of the economic systems.

\section{Acknowledgements}

The authors wish to thank participants to the ETSG 13th Annual Conference, to the WIOD Project Final Conference in Groningen and to seminars at Politecnico di Milano, Centro Studi Luca D'Agliano and University of Michigan for useful comments and suggestions. 


\section{References}

[1] WTO (2011) World Trade Report 2011. The WTO and Preferential Trade Agreements: From Co-Existence to Coherence. World Trade Organization, Geneva.

[2] Eaton, J., Kortum, S., Neiman, B. and Romalis, J. (2011) Trade and the Global Recession. NBER Working Paper No. 16666.

[3] Eichengreen, B. (2009) Comments in “Collapse in World Trade: A Symposium of Views”. The International Economy, Spring.

[4] Yi, K.-M. (2009) The Collapse of Global Trade: The Role of Vertical Specialization. In: Baldwin, R.E. and Evenett, S. Eds., The Collapse of Global Trade, Murky Protectionism, and the Crisis: Recommendations for the G20, 45-48. http://www.voxeu.org/sites/default/files/Murky_Protectionism.pdf

[5] Bridgman, B. (2013) International Supply Chains and the Volatility of Trade. Economic Inquiry, 51, $2110-2124$. http://dx.doi.org/10.1111/ecin.12009

[6] Ciccone, A. (2002) Input Chains and Industrialization. Review of Economic Studies, 69, 565-587. http://dx.doi.org/10.1111/1467-937X.t01-1-00022

[7] Jones, C. I. (2011) Intermediate Goods and Weak Links in the Theory of Economic Development. American Economic Journal: Macroeconomics, 3, 1-28.

[8] Feenstra, R. (1998) Integration of Trade and Disintegration of Production in the Global Economy. Journal of Economic Perspectives, 12, 31-50. http://dx.doi.org/10.1257/jep.12.4.31

[9] Hummels, D., Ishii, J. and Yi, K.-M. (2001) The Nature and Growth of Vertical Specialization in World Trade. Journal of International Economics, 54, 75-96. http://dx.doi.org/10.1016/S0022-1996(00)00093-3

[10] Johnson, R.C. and Noguera, G. (2012) Fragmentation and Trade in Value Added over Four Decades. NBER Working Paper No. 18186.

[11] Yi, K.-M. (2003) Can Vertical Specialization Explain the Growth of World Trade? Journal of Political Economy, 111, 52-102. http://dx.doi.org/10.1086/344805

[12] Escaith, H. (2009) Trade Collapse, Trade Relapse and Global Production Networks: Supply Chains in the Great Recession. MPRA Working Paper No. 18274.

[13] Kose, M.A. and Yi, K.-M. (2001) International Trade and Business Cycles: Is Vertical Specialization the Missing Link? American Economic Review, 91, 371-375. http://dx.doi.org/10.1257/aer.91.2.371

[14] Burstein, A., Kurz, C. and Tesar, L. (2008) Trade, Production Sharing and the International Transmission of Business Cycles. Journal of Monetary Economics, 55, 775-795. http://dx.doi.org/10.1016/j.jmoneco.2008.03.004

[15] Arkolakis, C. and Ramanarayanan, A. (2009) Vertical Specialization and International Business Cycle Synchronization. Scandinavian Journal of Economics, 111, 655-680. http://dx.doi.org/10.1111/j.1467-9442.2009.01580.x

[16] di Giovanni, J. and Levchenko, A.A. (2010) Putting the Parts Together: Trade, Vertical Linkages, and Business Cycle Comovement. American Economic Journal: Macroeconomics, 2, 95-124.

[17] Alessandria, G., Kaboski, J. and Midrigan, V. (2010) The Great Trade Collapse of 2008-09: An Inventory Adjustment? NBER Working Paper No. 16059.

[18] di Giovanni, J. and Levchenko, A.A. (2012) Country Size, International Trade, and Aggregate Fluctuations in Granular Economies. Journal of Political Economy, 120, 1083-1132. http://dx.doi.org/10.1086/669161

[19] di Giovanni, J., Levchenko, A.A. and Méjean, I. (2014) Firms, Destinations, and Aggregate Fluctuations. Econometrica, 82, 1303-1340. http://dx.doi.org/10.3982/ECTA11041

[20] Maggioni, A., Lo Turco, A. and Gallegati, M. (2014) Does Export Complexity Matter for Firms’ Output Volatility? Working Paper 407, Universita’ Politecnica delle Marche (I), Dipartimento di Scienze Economiche e Sociali.

[21] Jones, R., Kierzkowski, H. and Lurong, C. (2005) What Does Evidence Tell Us about Fragmentation and Outsourcing? International Review of Economics \& Finance, 14, 305-316. http://dx.doi.org/10.1016/j.iref.2004.12.010

[22] Antràs, P. and Helpman, E. (2004) Global Sourcing. Journal of Political Economy, 112, 552-580. http://dx.doi.org/10.1086/383099

[23] Escaith, H., Lindenberg, N. and Miroudot, S. (2011) Global Supply Chains, the Great Trade Collapse and Beyond: More Elasticity or More Volatility? In: Di Mauro, F. and Mandel, B., Eds., Recovery and Beyond. Lessons for Trade Adjustment and Competitiveness, European Central Bank e-Book, Frankfurt, 138-150.

[24] Baldone, S., Sdogati, F. and Tajoli, L. (2007) On Some Effects of International Fragmentation of Production on Comparative Advantages, Trade Flows and the Income of Countries. The World Economy, 30, 1726-1769. http://dx.doi.org/10.1111/j.1467-9701.2007.01054.x 
[25] Engel, C. and Wang, J. (2011) International Trade in Durable Goods: Understanding Volatility, Cyclicality, and Elasticities. Journal of International Economics, 83, 37-52. http://dx.doi.org/10.1016/j.jinteco.2010.08.007

[26] Levchenko, A., Lewis, L.T. and Tesar, L.L. (2010) The Collapse of International Trade during the 2008-2009 Crisis: In Search of the Smoking Gun. IMF Economic Review, 58, 214-253. http://dx.doi.org/10.1057/imfer.2010.11

[27] Feenstra, R. and Hanson, G. (1996) Globalization, Outsourcing and Wage Inequality. American Economic Review, 86, 240-245.

[28] Crinò, R. (2009) Offshoring, Multinationals and Labour Market: A Review of the Empirical Literature. Journal of Economic Surveys, 23, 197-249. http://dx.doi.org/10.1111/j.1467-6419.2008.00561.x

[29] Bergin, P.R., Feenstra, R.C. and Hanson, G.H. (2009) Offshoring and Volatility: Evidence from Mexico’s Maquiladora Industry. American Economic Review, 99, 1664-1671. http://dx.doi.org/10.1257/aer.99.4.1664

[30] Bergin, P.R., Feenstra, R.C. and Hanson, G.H. (2011) Volatility Due to Offshoring: Theory and Evidence. Journal of International Economics, 85, 163-173. http://dx.doi.org/10.1016/j.jinteco.2011.08.001 